ACTA THERIOLOGICA

Vol. 27, 4: $61-70,1982$

\title{
Banding Patterns on Chromosomes of the Lesser Shrew
}

\author{
Stanisław FEDYK \& Iwona MICHALAK
}

\begin{abstract}
Fedyk S., Michalak I., 1982: Banding patterns on chromosomes of the lesser shrew. Acta theriol., 27, 4: 61-70 [With 1 Fig. \& Plates I-II]

Examination was made of chromosomes of 14 lesser shrews (Sorex minutus Linnaeus, 1766) caught in the Białowieża Primeval Forest. Conventionally stained preparations showed that shrews of this population have 42 chromosomes which include 6 pairs of two-armed autosomes, while the remaining autosomes and sex chromosomes are single-armed. This chromosome formula is identical to that described earlier for the West European and Siberian populations. A detailed description is given in this paper of banding patterns on the chromosomes of Sorex minutus.

[Mammals Research Institute, Polish Academy of Sciences, 17-230 Białowieża].
\end{abstract}

\section{INTRODUCTION}

The Soricidae family, and among them particularly the genus Sorex, has formed the subject of a large number of cytogenetic studies. The reason for such interest is, on the one hand, the presence of chromosome polymorphism in Sorex araneus and, on the other hand, the fact that Insectivora form a very old, and to a very great degree morphologically conservative group of Eutheria.

During recent years there have been many studies describing the chromosome formulae of species of the genus Sorex (for review cf. Matthey, 1973a, b). Traditional systematics encountered great difficulties, impossible to overcome, in relation to the genus Sorex. Studies of a cytotaxonomic character, on the other hand, have gone far towards explaining many systematic problems. The staining techniques now in use for differentiating chromosomes makes very exact comparisons of chromosome formulae possible.

Chromosomes of Sorex minutus were described for the first time by Meylan (1965) on the basis of material originating from Switzerland. This author found 42 chromosomes in this species, and these results were confirmed by material originating from the Moscow district (Orlov \& Alenin, 1968), and from several Siberian populations (Fedyk \& Ivanitskaya, 1972; Kozlovsky, 1973). A description is given in the present paper of chromosomes in Sorex minutus stained either conventionally and by differentiating methods. 


\section{MATERIAL AND METHODS}

The material used in this study consisted of 14 shrews, 9 males and 5 females, caught during the period from August to October 1980. Trapping was carried out in the Białowieża Primeval Forest. Chromosame preparations were obtained by the direct method from the spleen and bone marrow. Colchicine (preparation Colchinéos, Laboratoires Houdé) was applied for a period varying from 15 minutes to 1 hour, aiming at increasing the percentage of elongated chromosomes by shortening the time for which colchicine acted. The air-drying preparations were left for $1-2$ days, after which they were digested with trypsin using Seabright's method (1971).

\section{DESCRIPTION OF THE CHROMOSOME FORMULA}

The Sorex minutus karyotype consists of 42 chromosomes: 12 twoarmed and 30 single-armed. Metacentric chromosomes $(\mathrm{m})$ form two pairs of the largest chromosomes (pairs no. 1 and 2) and one pair of small chromosomes (pair no. 17). Pairs no. 3 and 4 are formed by submetacentric chromosomes (sm), and pair no. 5 by subtelocentric chromosomes (st). The remaining 14 pairs of autosomes are formed by acrocentric chromosomes (a) of gradually decreasing dimensions. On some plates pair $\mathrm{nr}$. 20 appears to be two-armed, but this is not visible on the majority of metaphasal plates (Fig. 1, see Plate I).

The sex chromosomes are single-armed. The dimensions of $\mathrm{X}$-chromosome are similar to those of the largest single-armed autosomes (pairs 6-9), Y-chromosomes is small with dimensions similar to the smallest pair of autosomes (Fig. 1).

\section{BANDING PATTERNS}

The banding pattern in Sorex minutus is shown in the karyotype (Fig. 2, Plate II) and in diagram form in the karyogram (Fig. 3). The description given below presents the characteristic elements of the banded karyotype of Sorex minutus.

Pair no 1 - There is a characteristic, very dark band in the middle of arm $p$, with medium-dark bands on each side of it and in addition at the distal end of the chromosome there is a very narrow, dark band. There are two dark bands in the distal part of arm $q$, and two other dark bands near the centromere. In many cases these last two bands fuse in one block.

Pair no. 2- Two dark bands are characteristic of arm $p$ : one lies near the centromere, the second is wider, on the distal end of the chromosome, the latter sometimes appearing as a block composed of two bands. The medium-dark band is situated in the middle of arm $p$. Only one dark 
band lying near the distal end occurs on arm q, and two narrow mediumdark bands in the middle of this arm.

Pair no. 3-Arm $p$ has two characteristic deeply stained bands. Two bands occur in the distal part on arm $q$, which often fuse into one block, while there are two other bands - one wider and the other narrower, nearer the centromere.

Pair no. 4-Arm $p$ is very characteristic, has two dark bands, which unlike arm $3 p$ are further apart. The band lying near the centromere is wide and deeply stained. In many metaphasal plates the distal band is separated into two smaller ones. Two narrow, medium-dark bands, often fusing into one, lie on arm $q$ in the distal part and at a distance $1 / 4$ from the centromere there is a single, very dark band.

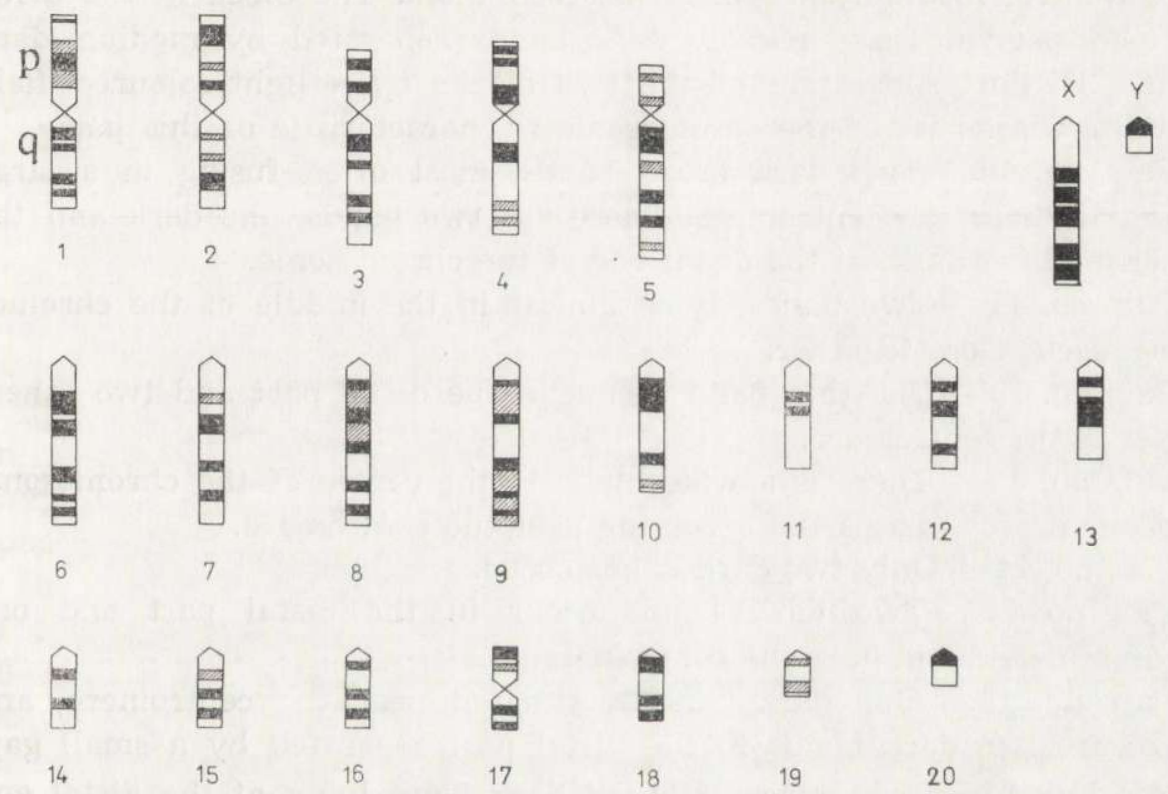

Fig. 3. Karyogramme of Sorex minutus with bands $G$ shown.

Black stripes indicate bands intensively stained, hatched stripes indicate places lightly stained.

Pair no. 5-Arm $p$ has no dark bands at all, only two medium-dark bands. There is a very dark wide band near the centromere on arm $q$ and behind it a narrow medium-dark band, then two narrow, dark bands and in the distal part a further very narrow paler band.

Pair no. 6-Near the centromere there is a very wide, dark block of two bands separated by a distinct light-coloured field from three other narrower bands, two of which, lying in the distal part of the chromosome, frequently fuse. 
Pair no. 7-There is a fairly large block of two bands, medium-dark and dark, near the centromere, while in the distal part there are two dark bands separated by a light-coloured space.

Pair no. 8-This pair is formed by chromosomes with only faintly delineated bands. Near the centromere there is a large block of medium intensity of staining (three narrow, dark bands with medium-stained bands lying between them). In the distal part there is a second but smaller block consisting of two bands, and this block is separated from the preceding one by a light-coloured space.

Pair no. 9- The chromosome of this pair, like those in pair no. 8, have no distinctly separated bands. There are also two medium-dark blocks. The block near the centromere consists of two narrow dark bands and a medium-dark band between them. The block in the distal part consists of three narrow dark bands separated by medium-dark bands. Distinct separation of the two blocks by a light-coloured field in the central part of the chromosome is characteristic of this pair.

Pair no. 10 - Two dark broad bands, most often fusing in a large block, lie near the centromere. There are two bands, one dark and the other medium-dark, at the distal end of the chromosome.

Pair no. 11 - Two bands, lying almost in the middle of the chromosome, occur close together.

Pair no. 12 - One thin band occurs in the distal part and two others closer to the centromere.

Pair no. 13 - There is a wide block in the centre of the chromosome and one narrow dark band occurring near the centromere.

Pair no. 14 - Only two dark bands occur.

Pair no. 15-Two dark bands occur in the distal part and one medium dark band near the centromere.

Pair no. 16-One dark band is situated near the centromere, and there are two dark bands in the distal part separated by a small gap.

Pair no. 17-Arm $p$ has a broad dark band lying at the distal end of the chromosome and a medium-dark band nearer the centromere. There are two dark bands on arm q. The pericentric region is not stained.

Pair no. 18 - One dark band lies near the centromere and two others, separated by a small gap, are situated at the distal end of the chromosome.

Pair no. 19 - Two medium-dark bands occur, the broader in the distal part and the narrower one near the centromere - there are no dark bands.

Pair no. 20-There is a thin dark band near the centromere.

$\mathrm{X}$-chromosome-There is an unstained region near the centromere, 
while the central part consists of a block composed of three dark bands; the distal end of the chromosome is occupied by a block of two dark bands - the two blocks are separated by a light space.

$\mathrm{Y}$-chromosome - There is a single dark band near the centromere.

\section{DISCUSSION}

The results of studies on the chromosome of Sorex minutus from a Swiss population (Meylan, 1765), from the Moscow district (Orlov \& Alenin, 1968) and from Siberia (Fedyk \& Ivanitskaya, 1972) are identical: 42 chromosomes were found. The present study provided confirmation that the same chromosome formula exists in the population from the Białowieża Primeval Forest. On the strength of these data it may be concluded that the karyotype of Sorex minutus is probably homogeneous over the whole area of occurrence of this species. It may also be concluded that there is a general absence of variation of chromosomes within this species.

Sorex minutus is the oldest of the contemporary species of the genus Sorex. This species was found to have occurred as early as the late Pliocene (Sulimski, 1962; Repenning, 1967). From the morphological aspect this is a form distinctly differing from the other species of the genus Sorex. The chromosomes of $S$. minutus confirm this status. The similarity of the number of chromosomes $(2 \mathrm{~N}=42)$ to those of species from the group $S$. centralis, S. unguiculatus, S. vir (cf. Fedyk \& Ivanitskaya, 1972) is fortuitous. The chromosome formula of these latter species greatly differ from that of $S$. minutus.

In respect of chromosomes the species most similar to Sorex minutus is the Caucasian species Sorex volnuchini Ognev, 1921 sensu Kozlovsky, 1973, and the Asiatic species Sorex buchariensis Ogniev, 1921 (Ivanitskaya et al., 1977). Forty chromosomes were found to be present in these two species, and their morphology is similar to that of the chromosome in $S$. minutus. The chromosome formulae of $S$. buchariensis and S. volnuchini are almost identical (Ivanitskaya et al., 1977). This latter species was described by Ognev as a sub-species Sorex minutus volnuchini, and its occurrence is limited to the north-eastern part of the Caucasus and Kouban (Ellermann \& Morrison-Scott, 1951). Sorex buchariensis, on the other hand, differs morphologically from S. minutus. The range of this species is also small, limited to part of Tadjikistan and the north-western Pamir Mountains (Ellermann \& Morrison-Scott, 1951). These are thus allopatric forms in relation to $S$. minutus, occurring on the south-eastern and of the latter's geographical range.

Sorex volnuchini was raised to the rank of species after examination of its chromosomes (Kozlovsky, 1973), since a separate chromosome 5 - Acta Theriologica 
formula, although similar to that of Sorex minutus, was found for it. Ivanitskaya et al. (1977), on the other hand, reached the conclusion after examination of chromosomes, that Sorex minutus, $S$. buchariensis and $S$. volnuchini have a common origin. This conclusion would appear correct, although it must be remembered that karyological similarities do not form a very strong argument in favour of their common origin. This applies particularly to Sorex buchariensis, a species whose morphological characterisics do not supply additional proofs of its common origin with the forms Sorex minutus and Sorex volnuchini. If, however, the above conclusion is taken as correct, it follows that these species form a group which from the karyological aspect differ from the other Paleoarctic shrews. It must also be concluded that this group relatively early separated from the common trunk and evolved independently.

Up to the present three groups of shrew have been distinguished on the basis of karyological studies (Fedyk \& Ivanitskaya, 1972). These are: (1) the group $S$. araneus $-S$. arcticus, to which, in addition to these two species, S. coronatus, $S$. daphaenodon and $S$. caucasicus are allocated. All these species have multiple sex chromosomes in males ( $\left.X, Y_{1} Y_{2}\right)$. Hausser et al. (1975) suggest that the Spanish species Sorex granarius Miller 1910 should probably also be allocated to this group. These authors described only the female karyotype $(2 \mathrm{~N}=34 ; \mathrm{NF}=38)$, and suggest that one of the two pairs of metacentric chromosomes are $\mathrm{X}$-chromosomes. Because the two-armed $X$-chromosomes occur only in the $S$. araneus $-S$. arcticus group, they conclude that Sorex granarius probably belongs to this group. It must, however, be emphasized that the morphological similarity between large metacentrics in Sorex granarius and $X$-chromosomes in the $S$. araneus - S. arcticus group (Hausser et al., 1975 had only conventionally stained preparations at their disposal) may be fortuitous only, and therefore until the male karyotype of $S$. granarius is known it is impossible to give a definite opinion as to the phyletic connections of this species.

(2) the 42-chromosome group of shrews, to which the following species belong: $S$. centralis (=S. isodon), $S$. unguiculatus, and $S$. vir. Since the classification proposed by Hoffmann (1971) for holarctic shrews was used as a basis in forming these groups, $S$. caecutiens, which also possess 42 chromosomes, was not included in this group.

(3) the group with karyotype intermediate between groups 1 and 2 . The Caucasian species Sorex raddei belongs to this group.

Král \& Ivanitskaya (1973) suggest the formation of a S. minutus $S$. cinereus group, consisting of the two oldest of all contemporary species which have been known since the Pliocene. Sorex cinereus is considered as a holarctic species, and has 66 chromosomes (Meylan, 1968). 
The amphi-Bering species, whose chromosomes are not known, are supposed to belong to this group. It would seem that Král and Ivanitskaya's suggestions (1973) as to connections between S. cinereus and East Siberian species and further, linking these forms with Sorex minutus, is a far-reaching speculation, at least from the karyological point of view.

Up to the present descriptions have been given of banding patterns only for certain species of shrew from the $S$. araneus $-S$. arcticus group: Sorex araneus ( $=S$. araneus race $B$ after Meylan, 1964) (Fredga \& Nawrin, 1977; Fedyk, 1980; Fedyk \& Michalak, 1980), Sorex coronatus (=S. araneus race $A$ after Meylan, 1964) (Gropp et al., 1973; Olert \& Schmid, 1978), Sorex arcticus - Siberian form (Král \& Radjabli, 1976). It would be interesting to compare the chromosome banding patterns of these species with $S$. minutus, but this would necessitate special comparative studies. At present it is only possible to state that the banding pattern of $X$-chromosome in Sorex minutus is similar to the banding pattern of the shorter arm of $X$-chromosome in Sorex araneus. It must be remembered that this arm is the primitive $X$-chromosome in $S$. araneus, while the second arm is a translocated autosome (Fredga, 1970) and in addition $X$-chromosomes are single-armed in the other species of the genus Sorex, apart from those belonging to the $S$. araneus $S$. arcticus group. It is therefore obvious that the above group had separated from the $S$. minutus group even before translocation of the $X$-autosome took place.

Apart from similarities in $X$-chromosome between $S$. minutus and $S$. araneus it proved impossible to find an identical banding pattern in any of the arms or even whole chromosomes of these two species, only certain parts of the chromosomes of the species being similar in appearance. It would only be possible to obtain confirmation of this by undertaking detailed comparative studies, nevertheless the absence of identical banding patterns may suggest that these two groups i. e., $S$. araneus $-S$. arcticus and $S$. minutus (assuming that the morphological similarities of the conventionally stained chromosomes of $S$. volnuchini and $S$. buchariensis are not fortuitous) separated from each other very early on, in the stage when the fusion process had not yet begun in the ancestors of the $S$. araneus $-S$. arcticus group.

Electrophoretic studies of enzymes provide some confirmation of this differentiation. It was found (Catzeflis, pers. commun.) that in respect of biochemical characteristic Sorex minutus (from the Swiss population) is closer to Sorex samniticus (the Italian form which in traditional systematics is considered as a synonym of Sorex araneus, cf. Corbet, 1978) than $S$. araneus and S. coronatus (from the Swiss population) and S. granarius (from the Spanish population). 
It may also be considered likely that banding patterns of chromosomes of species from the group of 42-chromosome shrews may be far more similar to $S$. minutus. There are so far no data available which could be used for such comparisons.

Acknowledgments: We wish to thank Miss Halina Bajko for her assistance with laboratory work and Messrs Stefan Buszko, Jerzy Siemieniuk and Witalis Szpakowicz for their help in catching shrews.

\section{REFERENCES}

1. Corbert G. B., 1978: The mammals of the Palaearctic region: a taxonomic review. Cornell Univ. Press, $1-314$, London.

2. Ellermann J. R. \& Morrison-Scott T. C. S., 1951: Checklist of Palaearctic and Indian mammals 1758 to 1946. British Mus. (Nat. Hist.), 1-810, London.

3. Fedyk S., 1980: Chromosome polymorphism in a population of Sorex araneus L. at Białowieża. Folia biol. (Kraków), 28: 83-120.

4. Fedyk S. \& Ivanitskaya E. Y., 1972: Chromosomes of Siberian shrews. Acta theriol., 27: 475-492.

5. Fedyk S. \& Michalak I., 1980: Description of chromosomes in a population of Sorex araneus L. living in the Biebrza valley. Folia biol. (Kraków), 28: 237-244 .

6. Fredga K., 1970: Unusual sex chromosame inheritance in mammals. Phil. Trans. Roy. Soc., London B, 259: 15-36.

7. Fredga K. \& Nawrin J., 1977: Karyotype variability in Sorex araneus L. (Insectivora, Mammalia). [In: "Chromosomes Today" vol. 6, A. de la Chapelle and M. Sorsa, eds]. Elsevier, North-Holland Biomed. Press, 153-161, Amsterdam.

8. Gropp A., Hilwing I. \& Seth P. K., 1973: Fluorescence chromosome banding patterns produced by a benzimidazole derivative. [In: "Chromosome identification - technique and applications in biology and medicine", T. Casperssom and L. Zech, eds]. Nobel Symp., 28: 300-306.

9. Hausser J., Graf J. D. \& Meylan A., 1975: Donneés nouvelles sur les Sorex d'Espagne at des Pyréneés (Mammalia, Insectivora). Bull. Soc. Vaud. Sci. Nat., 72: 241-252.

10. Hoffmann R. S., 1971: Relationships of certain Holarctic shrews, genus Sorex. Z. Säugetierunde, 46: 193-200.

11. Ivanitskaya E. Y., Isakov S. I. \& Korobitzyna K. V., 1977: Chromosome sets of two species of shrews from Tadjikistan, Sorex buchariensis Ognev, 1921 and Crocidura suaveolens Pallas, 1811. (Soricidae, Insectivora). Zool. Žurn., 56: 1896-1900. [in Russian].

12. Kozlovsky A. I., 1973: Results of karyological study of allopatric forms in Sorex minutus. Zool. Žurn., 52: 390-398. [in Russian].

13. Král B. \& Ivanitskaya Ye. (E.) Y., 1973: The history of ranges development of some groups of shrews, genus Sorex. [In: "The Bering land bridge and its role for the history of Holarctic floras and faunas in the late Cenozoic"]. 123-127, Khabarovsk.

14. Král B. \& Radjabli S. I., 1976; Koryotypes and G-bands of Western Siberian shrews Sorex araneus and S. arcticus (Insectivora, Soricidae). Zool. Listy, 25: $327-334$. 
15. Matthey R., 1973 a: The chromosome formulae of eutherian mammals. [In: "Cytotaxonomy and vertebrate evolution", A. B. Chiarelli and E. Capanna, eds]. Academic Press: 531-616, London.

16. Matthey R., 1973 b: Les nombers diploides des eutherians. Mammalia, 37: $394-421$.

17. Meylan A. 1964: Le polymorphisme chromosomique de Sorex araneus L. (Mamm. - Insectivora). Rev. suisse Zool., 71: 903-983.

18. Meylan A., 1965: La formule chromosomique de Sorex minutus L. (Mammalia -Insectivora). Experientia, 21: 268.

19. Meylan A., 1968: Formules chromosomiques de quelques petits mammiféres nord-americains. Rev. suisse Zool. 75: 691-696.

20. Olert J. \& Schmid M., 1978: Comparative analysis of karyotypes in European shrew species. I. The sibling species Sorex araneus and S. gemellus: Q-bands, G-bands and position of NORs. Cytogenet. Cell Genet., 20: 308-322.

21. Orlov V. N. \& Alenin V. P., 1968: Karyotypes of some species of shrews of the genus Sorex (Insectivora, Soricidae). Zool. Žurn., 47: 1071-1074. [in Russian].

22. Repenning C. A., 1967: Subfamilies and genera of the Soricidae. Geol. Survey Prof. Paper, 565: 1-74.

23. Seabright M., 1971: A rapid banding technique for human chromosomes. Lancet, 2: 971-972.

24. Sulimski A., 1962: Supplementary studies on the insectivores from Węże I (Poland). Acta paleontol. polonica, 7: 441-502.

Accepted, November 9, 1981.

Stanisław FEDYK i Iwona MICHALAK

WZORY PRĄZKOW NA CHROMOSOMACH SOREX MINUTUS LINNAEUS, 1766

\section{Streszczenie}

Zbadano chromosomy 14 osobników ryjówki malutkiej (Sorex minutus L.) odłowionych w Puszczy Białowieskiej. Preparaty chromosomowe robiono że śledziony i szpiku kostnego. Stwierdzono u S. minutus 42 chromosomy: 12 dwuramiennych oraz 30 jednoramiennych. Chromosomy pìci są jednoramienne, $\mathbf{X}-$ duży, $\mathbf{Y}-$ małych rozmiarów (Fig. 1). Podano szczegółowy opis prążków G u Sorex minutus (Fig. 2 i 3), stwierdzono jedynie podobieństwo wzoru prążków chromosomu $X$ u $S$. minutus do krótkiego ramienia chromosomu $\mathrm{X}$ u $S$. araneus. W dyskusji poruszono kwestie filogenetycznych powiązań między gatunkami Sorex minutus, Sorex volnuchini i Sorex buchariensis (tworzących grupę Sorex minutus), jak i cytogenetycznych zależności między ryjówkami z grupy $S$. minutus a innymi palearktycznymi gatunkami z rodzaju Sorex. 


\section{EXPLANATION OF PLATES I-II}

\section{Plate I.}

Fig. 1. Karyotype of Sorex minutus male.

In the separate frame are shown chromosomes of pair no. 20, with visible second arm orginated from the ather metaphasal plate.

Plate II.

Fig. 2. Banded Karyotype of Sorex minutus male. 
1

81 |1 18 |

।

5

B.

a 1

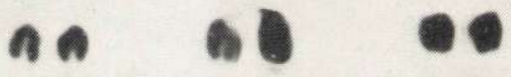

II

15

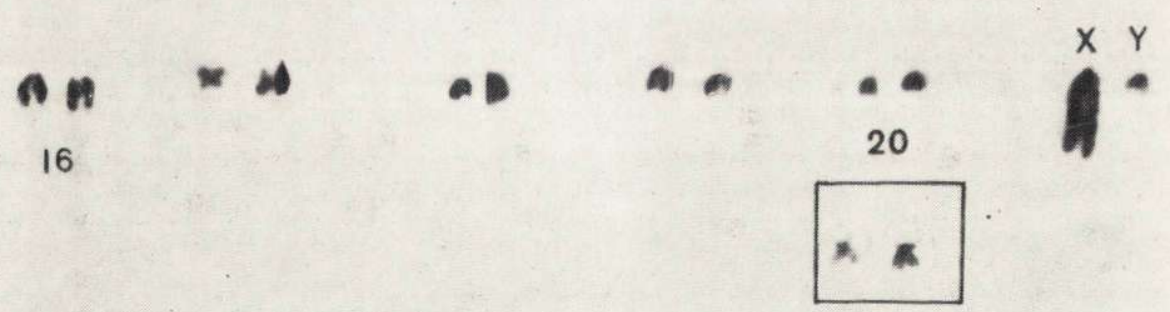

A Krishna \& C. J. Dominic

auctores phot. 


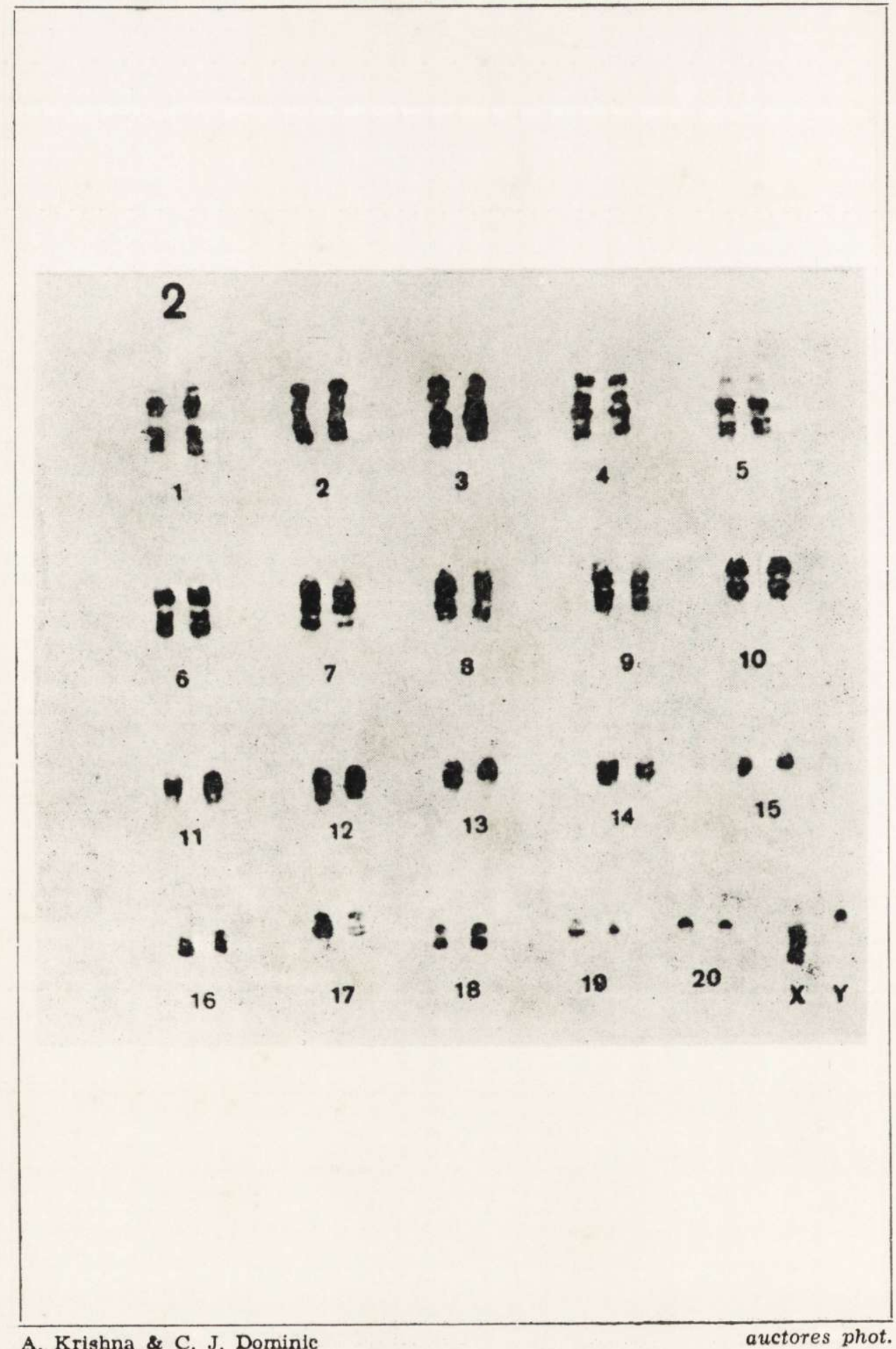

